\section{Stronger links with commerce urged in China}

\section{London}

CHINEsE scientists and technologists must be more prepared to talk business, according to Zeng Xianlin, vice-minister of the State Scientific and Technological Commission. Addressing a national forum of locally based science and technology enterprises in Beijing last month, Zeng said that too many Chinese scientists and technologists are hampered by the "outmoded notion" of looking down on business. Many consider that there are no prospects of engaging in science and technology businesses run by local people. Such erroneous and old-fashioned ideas, he said, should be repudiated.

The movement to create nongovernmental locally based science and technology businesses peaked in March 1985, when the Central Committee of the Chinese Communist Party issued a resolution on furthering the reform of the structure of science and technology. Since then, Zeng notes, most research organizations have instituted the technological contract system, and 390 have become economically independent. New technology markets have been opened up and developed, and some 87,000 'technological items' were transferred to the market during 1986. Employment structures have been changed, so that the senior appointments are made on the basis of qualifications and competence, not merely seniority. The most important thing, he says, is that society as a whole now attaches more and more importance to scientific and technological work, and the social status of intellectuals is being upgraded.

Some "defects" in the structure of science and technology still exist, he admits. Scientific and technological personnel are often "dispersed unreasonably", or criticized for doing part-time work in addition to their main jobs. There is still too much bureaucratic interference in the work of research departments, and many research units have not yet established the close relationship with industry recommended by the 1985 reforms. At the beginning of February, the State Council promulgated a number of new regulations on furthering the reform of science and technology. They recommend, on the one hand, the incorporation of independent research and design units into large and mediumsized enterprises; on the other, they encourage the establishment of cooperative relationships between industry and existing research centres and universities and of small technological development agencies operating on a contractual basis.

Vera Rich

\title{
Burst raises doubts about Soviet hydroelectricity dam
}

\section{London}

THE dam-burst at the Sargazon reservoir in Tadjik SSR last week with the loss of at least 19 lives has raised some doubts on the future of hydroelectric installations in the republic. In particular, the local Pravda correspondent, O. Latifi, has raised the question of the proposed Ziddin reservoir which would mean "millions of cubic metres of water hanging like the sword of Damocles" above Dushanbe, the Tadjik capital

The designs for the Ziddin project, Latifi complains, were elaborated "without any special publicity". Tadjikstan is a highly seismic area, and the construction of major hydroengineering works requires special consideration. Yet the Vaksh valley has become the site of a massive hydroelectric scheme in which a cascade of eight generating stations will have a combined generating capacity of 9,000 MW and an annual output of some 35,000 KWh.

The two most important stations are the Nurek (designed capacity 2,700 MW, recently upgraded to 3,000 MW) and the Regun, which, with a designed height of $345 \mathrm{~m}$ (40 m more than Nurek) will be the highest earthfill dam in the world.

At a recent 'round table' of representatives of the Tadjikstan Academy of Sciences organized at the Dushanbe Pravda offices, the scientists expressed their concern about the effect of high dams on the Vaksh valley. A large reservoir is an additional source of seismic stress, and the Nurek dam was built to designs based on the data for plains installations. Yet the effect of a seismic shock of a given magnitude is considerably greater in a mountainous region than in a plain. The torrential rains in the area, moreover, coupled with the low standard of civil engineering work in the republic, make subsidence and landslips a commonplace. Latifi does not suggest that low standards of work prevail at the Regun high dam, but there were reports last summer that bad coordination between the republic's electrical installation trust (Tadzhikglavenergo) and the All-Union Ministry of Power and Electrification had meant delayed and inadequate supplies, a situation in which pressure to meet target dates (already twice postponed) could easily lead to skimped or shoddy work. Tajikstan, moreover, like some 25 per cent of the mountain and foothill regions of the Soviet Union, is subject to mudflows. The Sargazon dam-burst was caused by such a mudflow, initiated by torrential rains. Research into mudflows has been going on in the Soviet Union since the 1930s, and there have been several All-Union conferences on the subject. Dams can, in theory, be protected against mud-flows by special mudcollectors, but these do not always prove effective. In July 1973, the impending devastation of Alma-Ata, capital of Kazakhstan was averted only by lastminute action by the State Emergency Commission to pump out the mud-collector at Medeo village. This installation was meant to be the main protection against mudflows for Alma-Ata, but in spite of the (then) more than 25 years of study of such flows, the planners ignored the scientists' recommendations, and design features were omitted.

Latifi's Pravda article does not mention the Alma-Ata incident. But something similar, he implies, may lie behind the Sargazon disaster. This tragedy, he says, must "become a lesson". For in it, there was "an element of miscalculation and irresponsibility".

Vera Rich

\section{Mary Rose still under water in dry dock}

The Tudor warship Mary Rose, sunk on 19 July 1545 and now on public view in dry dock in Portsmouth, is soon to start 'drying out'. The waterlogged timbers have to be sprayed with water for 20 hours in every 24. But now that the Mary Rose Trust has conserved all the wooden artefacts from the ship, attention turns to the hull which is to be preserved by a two-stage polyethylene glycol process developed by BP Chemicals.

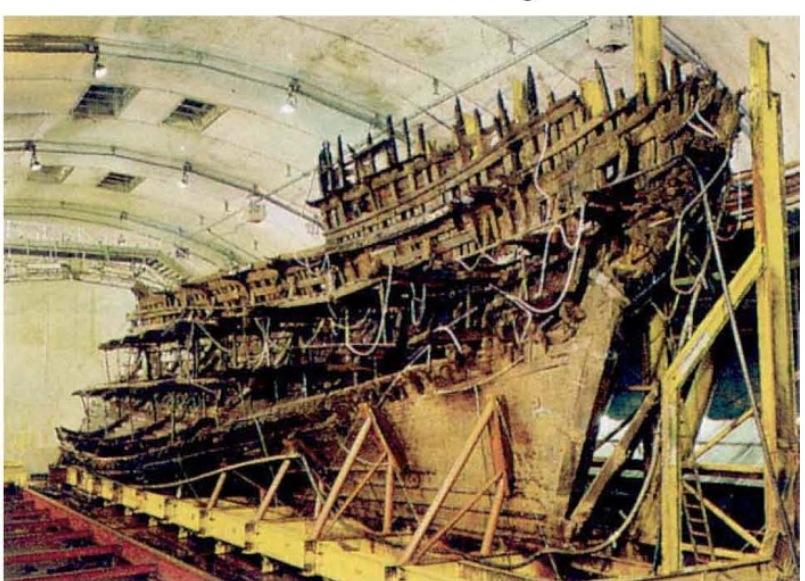

